\title{
THE ELEVATION NET FOR THE SALTWATER INTRUSION PHENOMENON ANALYSIS IN THE COASTAL PLAIN OF PISA
}

\author{
G. Caroti ${ }^{\mathrm{a}}$, A. Piemonte ${ }^{\mathrm{a}}, \mathrm{M}$. Redini $^{\mathrm{b}}$ \\ ${ }^{\text {a }}$ Laboratorio A.S.T.R.O., Dipartimento di Ingegneria Civile e Industriale, Università di Pisa, Largo Lucio Lazzarino 1 \\ 56123 PISA, tel 050221 7770, fax 050221 7779, e-mail gabriella.caroti@dic.unipi.it \\ ${ }^{\mathrm{b}}$ Comune di Pisa, m.redini@comune.pisa.it
}

KEY WORDS: Surveying, Hydrology, Environment, DEM/DTM, LIDAR, Georeferencing, Model

\begin{abstract}
:
In coastal plains, such as that of Pisa, with particular reference to groundwater, the marine intrusion phenomenon occurs not only through the freshwater/saltwater interface in the aquifer along the shore line, but also by the rise of the salt wedge in water courses, in case they are in hydraulic connection with the aquifer itself. The depth of the interface is primarily regulated by the hydrostatic freshwater/saltwater balance, that can be modified by anthropic exploitation of groundwater. To this day, seawater intrusion is considered one of the most extensive and important processes that degrade water quality through an increase in salinity levels up to values exceeding the standard for drinking water and irrigation systems, and endangering the future use of coastal waters. Given the potential hazard of the phenomenon, control wells are set up in order to monitor its evolution, allowing to perform routine in-well analyses aimed at measuring its characteristic parameters.

The essential foundation to reconstruct the freshwater/saltwater interface, and therefore also for the recognition of the phenomenon of seawater intrusion, is represented by piezometric reconstructions integrated with hydrogeochemical information that can be obtained directly from in-well measurements and indirectly through laboratory tests carried out on samples of water. A serious limitation of the piezometric reconstructions is mostly represented by the margin of approximation with which the elevation of water points has been established, which in turn result in uncertainty in the relationship between piezometric and hydrometric elevation. This paper presents various methodologies, GNSS and conventional, to determine the elevation of piezometers, also evaluating the accuracy obtainable and the requirements in terms of time, personnel and equipment.
\end{abstract}

\section{INTRODUCTION}

This work is part of a collaboration with the Municipality of Pisa - Office of Regional Planning for the study of saltwater intrusion on the Pisa coast.

In 2007, the City of Pisa has started the project "Implementation of a network for measurement, control and monitoring in the coastal plain of Pisa for the protection of water resources from salt wedge intrusion and other degradation".

It's long been known that the salinity of Pisa coastal freshwater is growing. Since 2007, the Municipality of Pisa is reconstructing, through the relevant observations, the trend, in both space and time, of the phenomenon, aiming at the identification of effective actions to mitigate it, in accordance with:

- the Regulation implementing Article 62 of the LR 03.01.05 n.

1 (Regulations for the government of the territory) in the field of geological investigations;

competences entrusted by Del. C. R. 30.01 .90 n.47 (Directive on coastal areas);

L.R. 21.05.07 n. 29 and subsequent amendments (Hydraulic emergencies).

There is an ongoing data collection activity aimed at:

- updating and detailed definition of the required knowledge base;

implementing the Directive on coastal areas (salt wedge progression);

updating of hydrogeological vulnerability maps accompanying the "Piano Strutturale";

creating a detailed cognitive framework to be made available to higher-level authorities and users

The objectives of this study are: the definition of salt wedge movements on the coast of Pisa in response to hydrological stress and water management practices in the surface aquifer;

the definition of temporary safeguard measures; the definition of mitigation actions.

The study area extends from the mouth of Fiume Morto Vecchio to the mouth of Calambrone, and coincides with the boundaries of the Municipality overlooking the coast, for a total of about $20 \mathrm{~km}, 12$ of which related to the stint Marina di PisaCalambrone (Figure 1 ).

The area is subject to multiple hydrological stress linked to incorrect practices of water resource management, which can be summarized as follows:

coastline recession;

pumping;

anthropogenic pressure (urban planning tools);

riverbeds (suspended riverbeds);

drainage system (minor networks, dewatering pumps).

Central to these primary objectives, is the need to unambiguously and correctly georeference the different databases coming from the various monitoring activities implemented for the study of the phenomenon. 


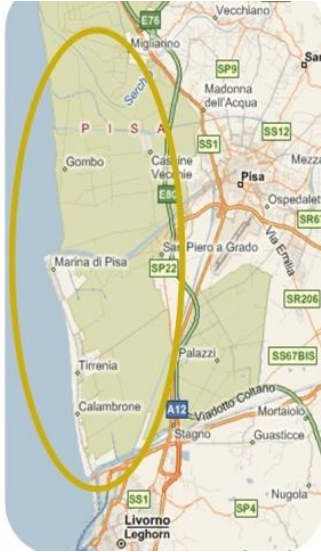

Figure 1. Study area

In this context, starting Jun 2009, the authors' contributions to the project of the Municipality included:

local check of the geoid model provided by the National Military Geographical Institute (Istituto Geografico Militare IGM);

measure of orthometric height in the vicinity of piezometric wells;

fixing of plano-altimetric position of network piezometers in the area of monitoring, showing applicable survey methods, taking into account not only the different levels of accuracy but also the requirements as for time, personnel and equipment resources.

\section{THE PHENOMENON OF SALT WEDGE}

In coastal plains, such as that of Pisa, with particular reference to groundwater, the marine intrusion phenomenon occurs not only in the aquifer along the shoreline through the freshwater / saltwater interface, but also by the rise of the salt wedge in water courses, in case these are in hydraulic connection with the aquifer itself.

The depth of the interface is primarily regulated by hydrostatic freshwater / saltwater balance, whose natural trend is modified by anthropic exploitation of groundwater.

Seawater intrusion is currently seen as one of the most extensive and important processes that degrade water quality, through an increase in the salinity level up to values exceeding the standard for drinking water and irrigation, also endangering future use of coastal waters.

In order to monitor the evolution of this potentially harmful phenomenon, control wells are set up to perform the routine analysis aiming to measure characteristic parameters of seawater intrusion.

The indispensable basis for reconstituting the freshwater / saltwater interface trend, and therefore also for the recognition of seawater intrusion phenomena, is represented by piezometric reconstructions, integrated with hydrogeochemical information obtained directly from in-well measurements and indirectly through laboratory tests carried out on samples of water.

A major limitation of piezometric reconstruction is mostly represented by the approximation with which the elevation of water points has been determined, which in turn results in problems of uncertainty in relating piezometric and hydrometric elevation.

\section{GEOLOGICAL AND HYDROGEOLOGICAL MODELS}

The Municipality of Pisa, in the study for the protection of water resources from salt wedge progression, has reconstructed a geological model of the subsurface referring the height of geognostic probing to an elevation model (DTM) derived from laser scanner surveys, available for the entire study area.

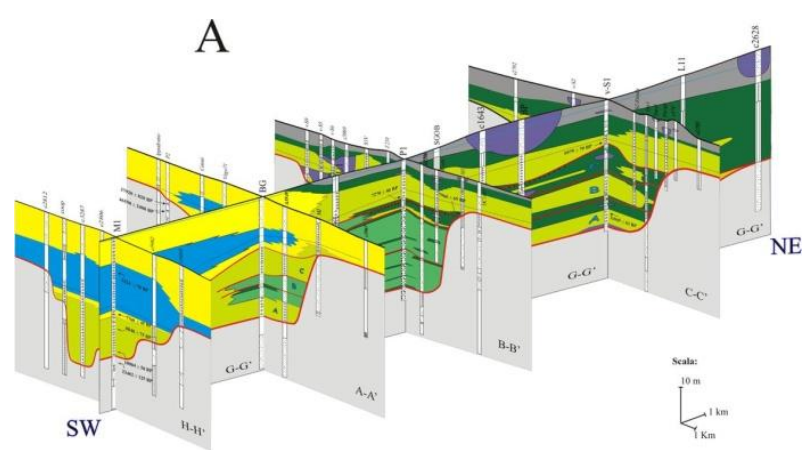

Figure 2. Geological model.

Based upon this subsurface geological model, a hydrogeological model, greatly detailing just the coastal strip and a wide area one, has been implemented.

The finite difference model ("visual modulo" software) set up for the hydrogeological modeling has the following features:

- resolution of the model in the large triangular area bound to the north by the Arno river, from the south to the east by the Scolmatore-Navicelli channel and to the west from the sea: $120 \mathrm{~m}$ by $133 \mathrm{~m}$ cells;

- resolution of the model in the town of Marina di Pisa and inland dunes: $68 \mathrm{~m}$ by $58 \mathrm{~m}$ cells;

- resolution of the model in the center of Tirrenia and inland dunes: $72 \mathrm{~m}$ by $68 \mathrm{~m}$ cells.

The modeling results have provided high-quality, highreliability data.

By way of example, Figure 3 shows the basic scenario for the area of Tirrenia, while Figure 4 shows the scenario with local reduction of the charge for the area of Marina di Pisa.

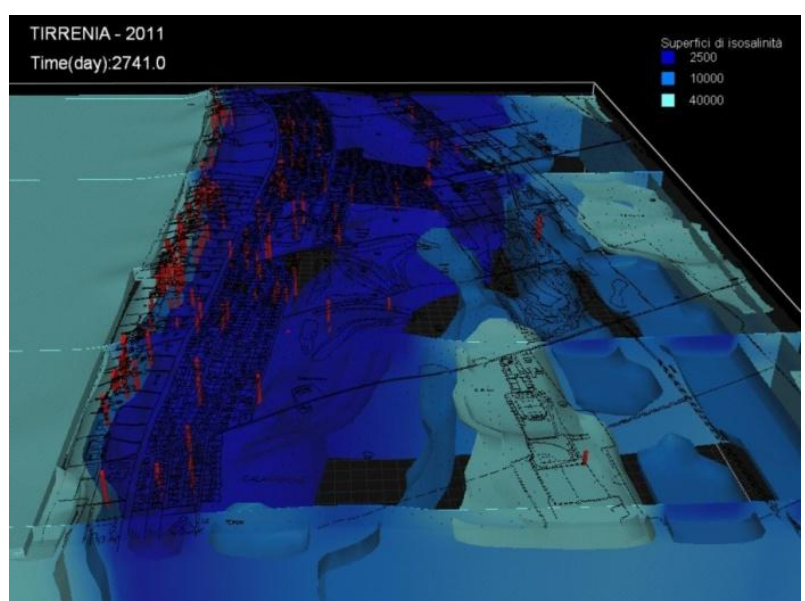

Figure 3. Baseline scenario for the Tirrenia area (3D view obtained by Modflow 3D Visual Explorer). Salinity distribution $(\mathrm{mg} / \mathrm{l})$ at the end of the simulation period (2017) 


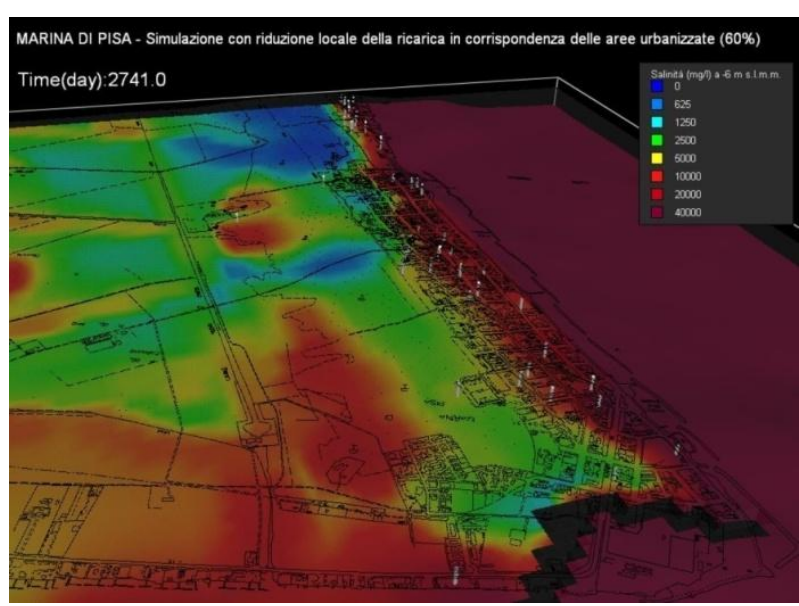

Figure 4. Scenario with local reduction of the charge for urban areas in the Marina di Pisa area (3D view obtained by Modflow 3D Visual Explorer). Salinity distribution at $-6 \mathrm{~m} \mathrm{~m}$ a.s.l. $(\mathrm{mg} / \mathrm{l})$ at the end of the simulation period (2017)

In order to compare the simulated information from the model with the actual situation of each location and to continuously collect hydrogeological information, 48 measurement points have been selected to set up a hydrological monitoring network.

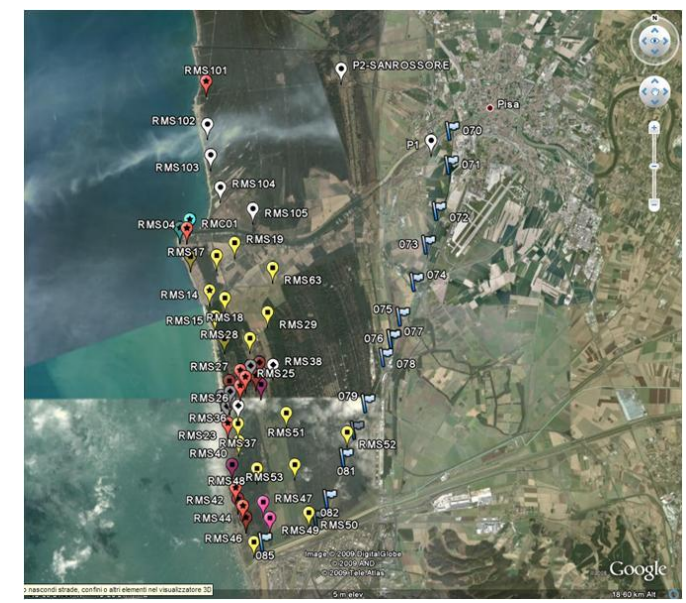

Figure 5. Hydrological monitoring network

The use of data provided by fixed control points on the territory as input for simulation models has required a previous check of the elevation of the well heads over the entire monitoring network and has led to a detailed analysis of different applicable survey methods.

\section{PLANO-ALTIMETRIC GEOREFERENCING OF PIEZOMETRIC WELLS}

The planimetric and altimetric coordinates of the 10 piezometric wells located along the Pisa coast have been determined by means of a real-time, phase differential GNSS survey. In particular, a Leica GPS1200+ system, connected via GPRS modem to the Italpos network server, has been used. The selected differential correction was single station CMR (Nearest) compared to the datum ETRS89 so that data were consistent with the other databases used.

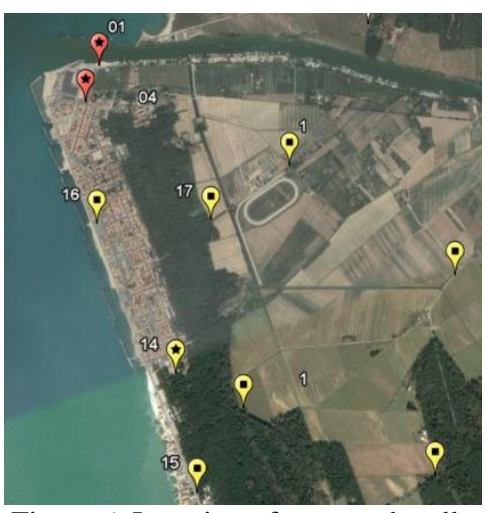

Figure 6. Location of surveyed wells

Since Italpos network station 0056 (Mada) is less than twelve kilometers away from the area in question, mode "Nearest" was chosen for consistency in the differential correction.

The accuracy degree of the survey was aligned with that expected from the methodology used (Table 1).

\begin{tabular}{|c|c|c|c|c|}
\hline Well & Latitude & Longitude & $\mathbf{h}_{\text {ell }}(\mathbf{m})$ & $h_{\text {ell }}$ STD (m) \\
\hline RMS01 & $43^{\circ} 40^{\prime} 44.44661 " \mathrm{~N}$ & $10^{\circ} 16^{\prime 28.81194 " \mathrm{E}}$ & 47.216 & 0.008 \\
\hline RMS04 & $43^{\circ} 40^{\prime} 35.45364 " \mathrm{~N}$ & $10^{\circ} 16^{\prime 25.01387 " \mathrm{E}}$ & 47.426 & 0.011 \\
\hline RMS16 & $43^{\circ} 40^{\prime} 05.15265^{\prime \prime} \mathrm{N}$ & $10^{\circ} 16^{\prime} 30.16503 " \mathrm{E}$ & 49.229 & 0.013 \\
\hline RMS14 & $43^{\circ} 39^{\prime} 29.59786 " \mathrm{~N}$ & $10^{\circ} 16^{\prime} 58.69312 " \mathrm{E}$ & 48.585 & 0.018 \\
\hline RMS18 & $43^{\circ} 39^{\prime} 21.08594 " \mathrm{~N}$ & $10^{\circ} 17^{\prime} 20.24294 " \mathrm{E}$ & 47.517 & 0.022 \\
\hline RMS15 & $43^{\circ} 39^{\prime} 02.74095^{\prime \prime} \mathrm{N}$ & $10^{\circ} 17^{\prime} 06.23424 " \mathrm{E}$ & 50.000 & 0.013 \\
\hline RMS29 & $43^{\circ} 39^{\prime} 06.57516 " \mathrm{~N}$ & $10^{\circ} 18^{\prime} 22.53573^{\prime \prime E}$ & 47.159 & 0.033 \\
\hline RMS63 & $43^{\circ} 39^{\prime} 53.44377^{\prime \prime N}$ & $10^{\circ} 18^{\prime 2} 29.78764 " \mathrm{E}$ & 47.048 & 0.011 \\
\hline RMS17 & $43^{\circ} 40^{\prime} 06.09466^{\prime \prime} \mathrm{N}$ & $10^{\circ} 17^{\prime} 08.30390^{\prime \prime} \mathrm{E}$ & 46.889 & 0.027 \\
\hline RMS19 & $43^{\circ} 40^{\prime} 19.77974 " \mathrm{~N}$ & $10^{\circ} 17^{\prime} 34.35587^{\prime \prime E}$ & 47.070 & 0.014 \\
\hline $\begin{array}{c}\text { RTCM } \\
\text { Ref } 0056\end{array}$ & $43^{\circ} 44^{\prime} 50.95870 " \mathrm{~N}$ & $10^{\circ} 21^{\prime} 57.83046 " \mathrm{E}$ & 56.871 & 0.000 \\
\hline
\end{tabular}

Table 1. Coordinates of wells by RTK.

To make the coordinates consistent with piezometric data, they have been transformed into Gauss-Boaga and orthometric height using *.gr2 IGM grids (Table 2).

\begin{tabular}{|c|c|c|c|}
\hline Well & North Roma40 (m) & East Roma40 $(\mathbf{m})$ & $\mathbf{H}_{\text {a.s. } . \text { (. }}(\mathbf{m})$ \\
\hline RMS01 & 4837027.970 & 1602773.644 & 0.745 \\
\hline RMS04 & 4836749.218 & 1602692.857 & 0.944 \\
\hline RMS16 & 4835816.156 & 1602822.565 & 2.712 \\
\hline RMS14 & 4834729.083 & 1603478.415 & 2.024 \\
\hline RMS18 & 4834473.956 & 1603965.185 & 0.946 \\
\hline RMS15 & 4833903.120 & 1603660.154 & 3.404 \\
\hline RMS29 & 4834048.092 & 1605367.575 & 0.568 \\
\hline RMS63 & 4835496.619 & 1605507.237 & 0.518 \\
\hline RMS17 & 4835858.398 & 1603676.245 & 0.374 \\
\hline RMS19 & 4836289.668 & 1604253.105 & 0.572 \\
\hline
\end{tabular}

Table 2. Cartographic coordinates Gauss-Boaga (North, East) and elevation above mean sea level of well heads.

In two of the piezometric wells (RMS01 and RMS04) check points were materialized at the side of the well head within the same casing, while in the remaining cases the same spot used for piezometric level measurements, on the edge of the PVC pipe coating the well, has been used.

Transformation from ellipsoidal to orthometric heights, through the undulation provided by *.gr2 IGM grids, has been tested in the field, as shown in the next section. 


\section{VERIFICATION OF ACCURACY OF GEOID MODEL PROVIDED BY IGM IN THE MONITORING AREA}

The network of piezometric wells surveyed covers the area between the mouth of the Arno River and the mouth of Calambrone, for a total of about $12 \mathrm{~km}$.

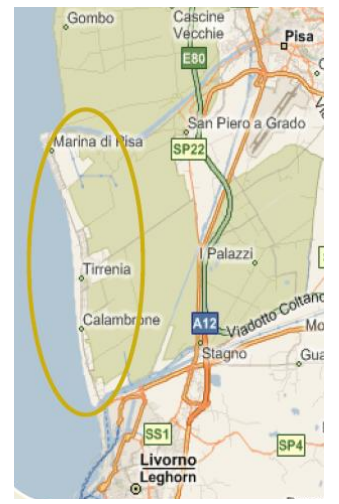

Figure 7. Survey area

In this area, IGM leveling lines do not run along the coast, as shown in Figure 8, and benchmark "104610", placed near the mouth of Arno along its left bank on the Lamone canal bridge, has been torn, presumably due to road maintenance. The only extant benchmark next to the monitoring area is that on the right bank of Arno (0031\#_D01_010 \#), on the platform of the Italian Navy Commandos base.

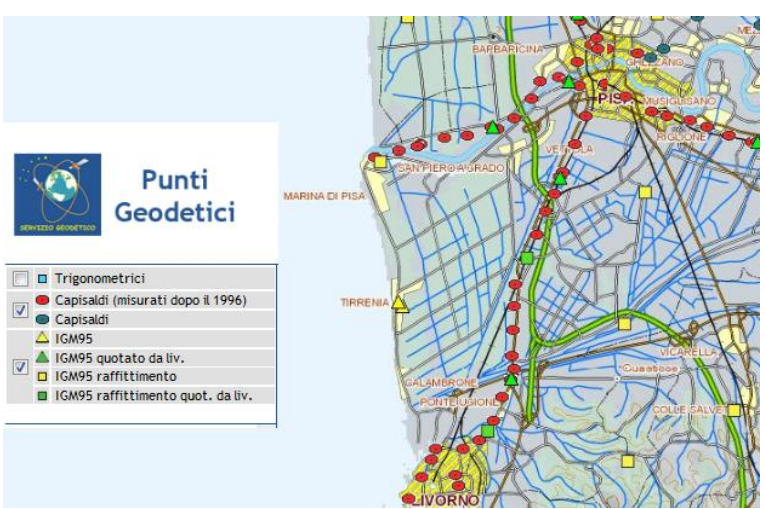

Figure 8. Distribution of leveling lines along the Pisa coast

In order to verify the local accuracy of the IGM geoid model, a triangular mesh GPS network, meeting the requirements of the State-Regions Agreement for the thickening of the IGM95 base network, has been established and measured.

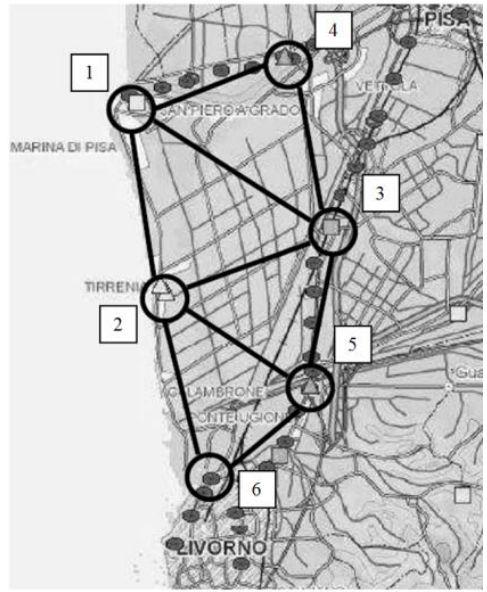

Figure 9. Static GPS survey network

The network consists of 6 vertices, already included in the IGM95 network or national elevation network, detailed as follows:

1- 0031\#_D01_010\#, benchmark not connected to the IGM95 network. Platform of the Italian Navy Commandos base, Bocca d'Arno - San Rossore;

2- 111901ass., IGM95 network benchmark. Piazza dei Fiori, Tirrenia;

3- 111604, IGM95 network thickening point with benchmarkbased elevation. "Scalo Mortellini", SS1 km 327.100;

4- 104701, IGM95 network point with benchmark-based elevation. "Cascine Nuove", San Rossore Park Area;

5- 111703, IGM95 network point with benchmark-based elevation. Wall of the Arno drainage canal bank, Stagno;

6- 0028\#_D02_001\#, benchmark not connected to the IGM95 network. Piazzale Zara (harbor area), Livorno.

The survey was carried out with 6 dual-frequency GPS receivers, used simultaneously on the network vertices.

The network has been compensated by imposing a constraint on the vertex labeled "111901ass.", (Figure 10) and the results have provided the ETRS89 coordinates of the vertices as reported in Table 3.

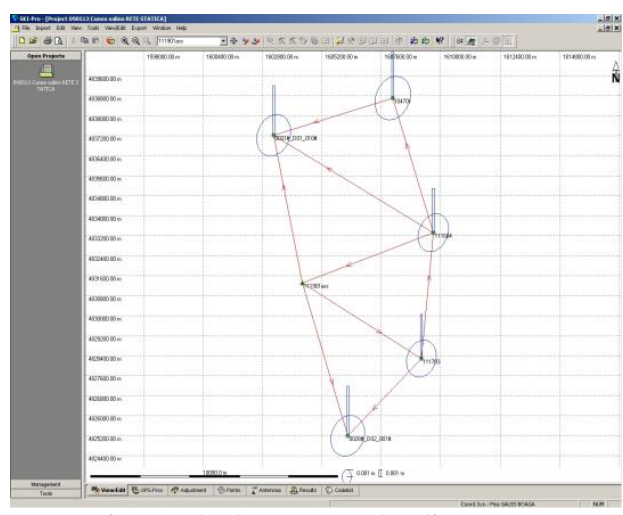

Figure 10. GPS network adjustment

\begin{tabular}{|r|c|c|c|}
\hline Network benchmarks & Latitude & Longitude & $\mathbf{h}_{\text {ell }}(\mathbf{m})$ \\
\hline 0031\#_D01_010\# & $43^{\circ} 40^{\prime} 50.57456^{\prime \prime} \mathrm{N}$ & $10^{\circ} 16^{\prime} 50.25472^{\prime \prime} \mathrm{E}$ & 47.474 \\
\hline std (m) & 0.003 & 0.002 & 0.007 \\
\hline \hline $111901 \mathrm{ass}^{*}$ & $43^{\circ} 37^{\prime} 38.53770^{\prime \prime} \mathrm{N}^{*}$ & $10^{\circ} 17^{\prime} 38.34670^{\prime \prime} \mathrm{E}^{*}$ & $51.461^{*}$ \\
\hline std $(\mathrm{m})$ & fixed & fixed & fixed \\
\hline 111604 & $43^{\circ} 38^{\prime} 40.89172^{\prime \prime} \mathrm{N}$ & $10^{\circ} 21^{\prime} 35.96315^{\prime \prime} \mathrm{E}$ & 51.014 \\
\hline std $(\mathrm{m})$ & 0.003 & 0.002 & 0.006 \\
\hline 104701 & $43^{\circ} 41^{\prime} 36.17523^{\prime \prime} \mathrm{N}$ & $10^{\circ} 20^{\prime} 26.16833^{\prime \prime} \mathrm{E}$ & 50.628 \\
\hline
\end{tabular}




\begin{tabular}{|r|c|c|c|} 
std (m) & 0.003 & 0.003 & 0.007 \\
\hline 111703 & $43^{\circ} 35^{\prime} 57.90374 " \mathrm{~N}$ & $10^{\circ} 21^{\prime} 10.69261 " \mathrm{E}$ & 50.899 \\
\hline std (m) & 0.003 & 0.002 & 0.006 \\
\hline 0028\#_D02_001\# & $43^{\circ} 34^{\prime} 19.24400 " \mathrm{~N}$ & $10^{\circ} 18^{\prime} 56.08950^{\prime \prime} \mathrm{E}$ & 49.100 \\
\hline std (m) & 0.003 & 0.002 & 0.007 \\
\hline
\end{tabular}

Table 3. Coordinates of the vertices of the IGM network from static survey

The transformation of the GPS network coordinates from ETRF89 to Gauss-Boaga Roma40 and orthometric height, performed with Verto software and *.gr2 grid referred to the 2005 geoid model (with an average deviation of $\pm 0.04 \mathrm{~m}$ with respect to the high precision leveling lines) gave the results shown in Table 4.

\begin{tabular}{|c|c|c|c|}
\hline Network benchmarks & North Roma40 (m) & East Roma40 (m) & $\mathbf{H}_{\text {a.s.l. }}(\mathrm{m})$ \\
\hline 0031\#_D01_010\# & 4837224.405 & 1603250.837 & 1.009 \\
\hline 111901ass & 4831316.483 & 1604419.994 & 4.753 \\
\hline 111604 & 4833325.282 & 1609713.593 & 4.369 \\
\hline 104701 & 4838707.647 & 1608062.546 & 4.185 \\
\hline 111703 & 4828287.624 & 1609229.321 & 4.031 \\
\hline 0028\#_D02_001\# & 4825195.419 & 1606259.588 & 2.098 \\
\hline
\end{tabular}

Table 4. ETRF89 to Gauss-Boaga transformation with *.gr2 grid

A first comparison in order to assess the accuracy achieved in the survey, in both planimetry and elevation, was performed on those vertices whose ETRF89 coordinates were reported on monograph.

Table 5 shows that the differences in planimetric coordinates are not significant and those in ellipsoidal height assume values ranging from a minimum of about $2 \mathrm{~cm}$, for point 104701, to a maximum of about $7 \mathrm{~cm}$, for point 111703: the precision obtained in height falls therefore within the degree of accuracy with which this type of survey returns elevation measures.

\begin{tabular}{|r|c|c|c|}
\hline $\begin{array}{c}\text { Network } \\
\text { benchmarks }\end{array}$ & $|\mathbf{D f}|$ & $|\mathrm{D} 1|$ & Dh $_{\text {ell }}(\mathbf{m})$ \\
\hline 111901 ass* & $0.00000^{\prime \prime}$ & $0.00000^{\prime \prime}$ & 0.000 \\
\hline 111604 & $0.00308^{\prime \prime}$ & $0.00145^{\prime \prime}$ & -0.046 \\
\hline 104701 & $0.00047^{\prime \prime}$ & $0.00013^{\prime \prime}$ & -0.019 \\
\hline 111703 & $0.00016^{\prime \prime}$ & $0.00041^{\prime \prime}$ & 0.069 \\
\hline
\end{tabular}

Table 5. Comparison of ETRF89 coordinates of IGM points from monographs vs. ETRF89 coordinates from static GPS survey

The IGM-supplied geoid model provided has been locally checked on those network points whose monograph reported the elevation relative to a benchmark.

Table 6 shows the undulation of the geoid as assessed by benchmark derived elevation, while in Table 7 the undulation was assessed by determining the orthometric height from the IGM 273.gr2 grid.

\begin{tabular}{|r|c|c|c|}
\hline Network benchmarks & $\mathbf{h}_{\text {ell }}(\mathbf{m})$ & $\mathbf{H}_{\text {a.s.l. }}(\mathbf{m})$ & $\mathbf{N}(\mathbf{m})$ \\
\hline 0031\#_D01_010\# & 47.474 & 0.999 & 46.475 \\
\hline 111604 & 51.014 & 4.357 & 46.657 \\
\hline 104701 & 50.628 & 4.187 & 46.441 \\
\hline 111703 & 50.899 & 4.095 & 46.804 \\
\hline 0028\#_D02_001\# & 49.100 & 2.121 & 46.979 \\
\hline
\end{tabular}

Table 6: Geoid undulation assessed by benchmark derived elevations

\begin{tabular}{|r|c|c|c|}
\hline Network benchmarks & $\mathbf{h}_{\text {ell }}(\mathbf{m})$ & $\mathbf{H}_{\text {a.s.l. }}(\mathbf{m})$ & $\mathbf{N}(\mathbf{m})$ \\
\hline 0031\#_D01_010\# & 47.474 & 1.009 & 46.465 \\
\hline $111901 \mathrm{ass}$ & 51.461 & 4.753 & 46.708 \\
\hline 111604 & 51.014 & 4.369 & 46.645 \\
\hline 104701 & 50.628 & 4.185 & 46.443 \\
\hline 111703 & 50.899 & 4.031 & 46.868 \\
\hline 0028\#_D02_001\# & 49.100 & 2.098 & 47.002 \\
\hline
\end{tabular}

Table 7: Geoid undulation assessed by grid-derived orthometric height (IGM 273.gr2 grid)
Table 8 shows the undulation differences for each point, between that assessed by benchmark derived elevations and that assessed by grid-derived orthometric height (IGM 273.gr2 grid).

\begin{tabular}{|r|c|}
\hline Network benchmarks & DN $(\mathbf{m})$ \\
\hline 0031\#_D01_010\# & 0.010 \\
\hline 111604 & 0.012 \\
\hline 104701 & -0.002 \\
\hline 111703 & -0.064 \\
\hline 0028\#_D02_001\# & -0.023 \\
\hline
\end{tabular}

Table 8: Differences between the undulation derived from benchmarks and from the IGM grid 273.gr2

From the results shown in Table 8 it can be seen as the ITALGEO2005 model respects locally declared accuracy (deviation values contained within $\pm 0.04 \mathrm{~m}$ ) but for point "111703" whose deviation is $-0.064 \mathrm{~m}$.

Table 5 shows that this point has an equal amount shift on the ellipsoidal elevation. This may suggest that this point has been tampered with.

\section{CONNECTION OF PIEZOMETRIC SURVEY POINTS WITH THE ALTITUDE NATIONAL NETWORK}

The preceding paragraph pointed out the fact that in this area IGM leveling lines do not run along the coast and the closest benchmark to the monitoring area (benchmark "104610") located along the Arno left bank has been completely altered. The only extant benchmark in the immediate surroundings is that on the right bank of the Arno (node 1 of the GPS network, IGM name_D01_010 \# 10031 \#) on the platform of the Italian Navy Commandos base.

The first necessity was to carry its elevation from the right bank to the left bank of the river Arno.

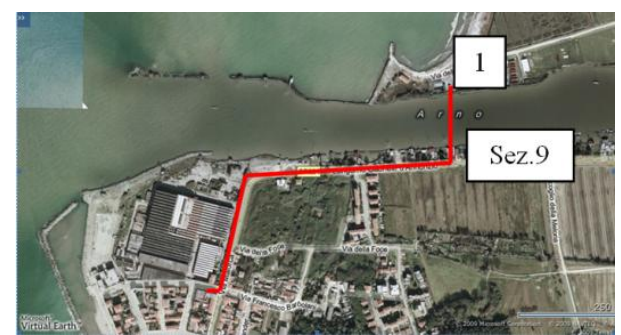

Figure 11. Connection of the wells to the national leveling network

In order to establish an altimetric connection between the two banks (about $130 \mathrm{~m}$ away) a reciprocal geometric leveling was performed between IGM benchmark "10031\#_D01_010\#” and benchmark "sezione 9" established by the Hydrographic and Tidal Office of the Municipality of Pisa on the left bank (with orthometric height derived from GPS survey). 


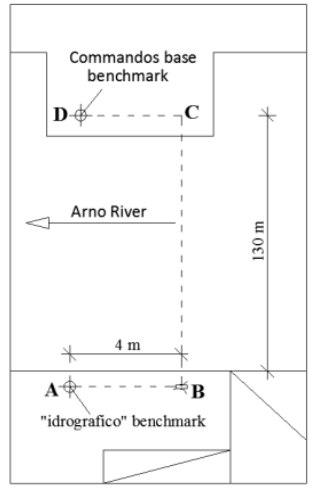

Figure 12. Altimetric connection by reciprocal leveling between two benchmarks placed on opposite sides of the Arno river

For this purpose, a Wild NA2 level with a Wild GPM3 parallel plate micrometer, and two Wild GPLE2 double graduation invar leveling rods, have been used.

The orthometric height of benchmark of the Hydrographic and Tidal Office of the Municipality of Pisa was equal to:

$$
\mathrm{H}_{\text {sezione }} 9^{\prime \prime}=0.79031+/-0.00019 \mathrm{~m}
$$

This benchmark originated a leveling line connecting the benchmarks established for the elevation reference of the well heads.

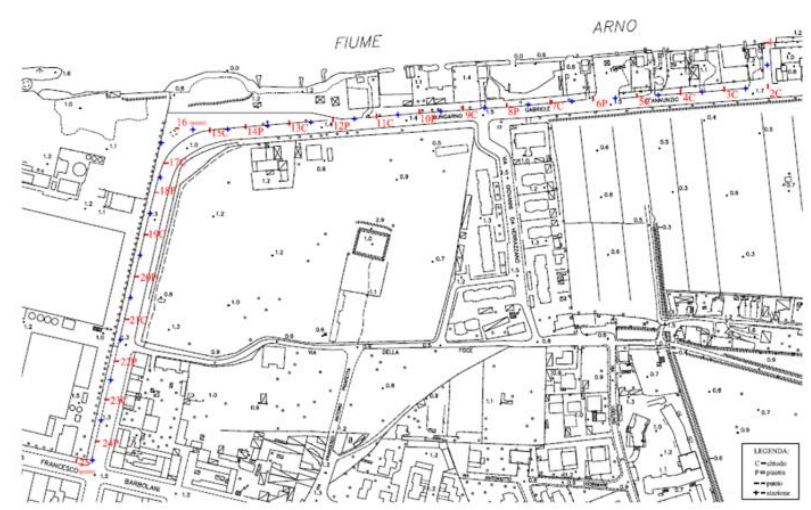

Figure 13. Leveling line between benchmark "sezione 9" and piezometric wells

Table 9 shows the leveling elevation of two wells and their differences compared to orthometric height by RTK survey.

\begin{tabular}{|c|c|c|c|}
\hline Well & $\mathbf{H}_{\text {a.s.l. }}(\mathbf{m})$ from lev. $(\mathbf{m})$ & $\mathbf{H}_{\text {a.s.l. }}$ from RTK $(\mathbf{m})$ & $\mathrm{D}_{\text {a.s.l. }}(\mathbf{m})$ \\
\hline RMS01 & 0,82628 & 0.745 & 0,08128 \\
\hline RMS04 & 1,02128 & 0.944 & 0,07728 \\
\hline
\end{tabular}

Table 9. Orthometric heights from leveling of two wells and comparison with those determined by RTK

\section{ALTIMETRIC GEOREFERENCING THROUGH DENSE DTM}

For the area of the Pisa coast affected by the phenomenon of the salt wedge a dense digital elevation model, with accuracy $<10 \mathrm{~cm}$, is available.

This elevation model has been used as a basis for hydrogeological modeling as described in section 3 .

This is based on a simplified mesh elevation model, resampled with cell size of about one hundred meters.

It is apparent that this simplification leads to use an average value of altitude data for the individual cells.
It was therefore decided to test the accuracy with which the elevation of the well heads can be extrapolated directly from the DTM.

The elevation values at the planimetric coordinates detected by RTK GPS were obtained by bilinear interpolation from the DTM. Those values were, therefore, corrected to take account of the fact that the point surveyed by GPS, coinciding with the reference point of the piezometric measurements, is located within a manhole lowered by a few tens of centimeters with respect to the pavement or road surface.

The comparison of elevation values interpolated from DTM with those obtained by the transformation of ellipsoidal height via the IGM 273.gr2, yields deviations in the order of a few centimeters (Table 10).

\begin{tabular}{|l|c|c|c|c|c|c|c|}
\hline Well & $\begin{array}{c}\text { Ellipsoid } \\
\text { heights } \\
\mathrm{h}(\mathrm{m})\end{array}$ & $\begin{array}{c}\text { Orthometric } \\
\text { heights } \\
\text { calculated } \\
\text { by IGM's } \\
\text { grid *.gr2 } \\
\mathrm{H}(\mathrm{m})\end{array}$ & $\begin{array}{c}\text { Interpolated } \\
\text { heights } \\
\text { from inland } \\
\mathrm{DTM} \\
\mathrm{H}_{\mathrm{i}}(\mathrm{m})\end{array}$ & $\begin{array}{c}\text { Interpolated } \\
\text { heights } \\
\text { from } \\
\text { coastal } \\
\text { DTM } \\
\mathrm{H}_{\mathrm{c}}(\mathrm{m})\end{array}$ & $\begin{array}{c}\text { Wellhead } \\
\text { heights } \\
\text { ground } \\
\text { level } \\
\text { heights } \\
\mathrm{dH}(\mathrm{m})\end{array}$ & $\begin{array}{c}\mathrm{H}-\mathrm{H}_{\mathrm{i}}-\mathrm{dH} \\
(\mathrm{m})\end{array}$ & $\begin{array}{c}\mathrm{H}-\mathrm{H}_{\mathrm{c}}-\mathrm{dH} \\
(\mathrm{m})\end{array}$ \\
\hline RMS01 & 47.216 & 0.745 & - & 1.011 & -0.25 & - & -0.016 \\
\hline RMS04 & 47.426 & 0.944 & - & 1.054 & -0.16 & - & 0.050 \\
\hline RMS16 & 49.229 & 2.712 & - & 2.955 & -0.27 & - & 0.027 \\
\hline RMS14 & 48.585 & 2.024 & - & 2.156 & -0.29 & - & 0.158 \\
\hline RMS18 & 47.517 & 0.946 & 1.306 & 1.156 & -0.28 & -0.080 & 0.070 \\
\hline RMS15 & 50.000 & 3.404 & 3.808 & 3.794 & -0.36 & -0.044 & -0.030 \\
\hline RMS29 & 47.159 & 0.568 & 0.995 & - & -0.29 & -0.137 & - \\
\hline RMS63 & 47.048 & 0.518 & 0.843 & - & -0.26 & -0.065 & - \\
\hline RMS17 & 46.889 & 0.374 & 0.913 & 0.880 & -0.28 & -0.264 & -0.231 \\
\hline RMS19 & 47.070 & 0.572 & 0.791 & 0.781 & -0.19 & -0.029 & -0.019 \\
\hline
\end{tabular}

Table 10. Orthometric elevations derived from DTM and comparison with those derived from RTK GPS

\section{CONCLUSIONS}

The interest in this study was to verify and compare the different methods by means of which hydrological monitoring points, established for the study of the phenomenon of the salt wedge on the Pisa coast, can be altimetrically framed.

This study has resulted in the creation of hydrogeological models for which the definition of the orthometric height of soil and groundwater is paramount. Firstly, these points have been detected by phase interference GPS survey and the local transformation from ellipsoidal to orthometric height via IGM *.gr2 grids has been positively validated.

The availability of a high precision and dense digital model has shown that the height of the same spots can be extrapolated by the elevation model with accuracies of a few centimeters.

To complete the survey on the different methodologies for altimetric framing, the network of piezometric monitoring points was also connected to a high-precision national leveling benchmark, with the leveling lines measured with classical methodology. This survey has of course produced very highprecision data, commensurate with the requirements in both time and resources inherent with the methodology in itself.

Provided this picture of precision obtainable in altimetric framing, firms and offices involved in hydraulic modeling have been allowed to decide which method to adopt based on financial and time resources.

\section{REFERENCES}

Ambrosio, M., Curcio, C., Fagioli, M., Giannecchini, R., 2011. L'acquifero freatico costiero della Pianura di Pisa tra Fiume Arno e Canale Scolmatore: implementazione e calibrazione del modello numerico. In Geologia Tecnica e Ambientale, ISBN 1722-0025. 
Bitelli, G., Roncari, G., Tini, M. A., Vittuari, L., 2011.

Metodologia per la determinazione con alta precisione del dislivello esistente tra due punti nell'attraversamento di zone impraticabili. In Atti $15^{a}$ Conferenza Nazionale ASITA. Pp. 363371.

Butteri, M., Doveri, M., Giannecchini, R., Gattai P., 2010. Hydrogeologic-hydrogeochemical multidisciplinary study of the gravel confined aquifer in the coastal Pisan Plain (Tuscany) between the Arno River and Scolmatore Canal (Tuscany). In Memorie Descrittive della Carta Geologica d'Italia, Vol. 90, 51-66.

Caroti, G., Piemonte, A., 2011. Analisi dei dati altimetrici disponibili per il territorio comunale di Pisa. In Geomatica le radici del futuro, Edizioni SIFET, ISBN 88-901939-6-4, pp. 157-161.

NOAA Sentinel Site Program, 2011. "Accurate Elevations for Sea Level Change Sentinel Sites".

ftp://www.ngs.noaa.gov/dist/phensel/Reviews/Matt_Kimball/A

_E_f_S_L_R_S_S_092911_MEK_Comments.pdf 